\title{
Method for determining iodine-127 in soils
}

\begin{abstract}
A method was presented for determining the content of stable iodine-127 ( $\left.{ }^{127} \mathrm{I}\right)$ in soil samples. The method is based on the reaction rate of cerium cation (IV) with arsene (III) anion. The rate of this reaction is catalysed with the amount of iodide anions $\left(\mathrm{I}^{-}\right)$in a mineralised soil sample. The method is precise, with repeatable results, and it is ready for common application. The method was verified with the use of an analytical sample manufactured by POCH SA: TitraFix ${ }^{\mathrm{TM}}$ analytical sample of potassium iodateiodide $0.05 \mathrm{~mol} \cdot \mathrm{dm}^{-3} \mathrm{I}_{2}(0.1 \mathrm{~N})$, (index: $743110161-020-1$, tolerance range: $\pm 0.2 \%$ ).
\end{abstract}

Keywords: iodine, soil, determination method

\section{INTRODUCTION}

So far, Polish researchers have used different methods for determining iodine in soils. The first one was Chudecki (1963), who applied Dragomirova's method (1944) in his studies of iodine content in the soils of Western Pomerania. Then, Kollender-Szych (1983a, 1983b) used Borst Pauwels and Wasemael's method for determining iodine content is the soils of the Sudetes, modifying it slightly. For determining the content of iodine in the soils of the Bieszczady Mountains, Uziak and Melke (1984) used Proskuriakova and Nikitina's method (1976), whereas Laskowski et al. (2001) used the method described in this article for determining the content of iodine in the soils of the Pilica and Ner valleys.

The method of neutron activation (NAA) is also effective for determining iodine-127 in the soil. It involves bombarding iodine-127 with a beam of neutrons. A nuclear reaction occurs and a heavier isotope is formed: iodine-128. It is the only isotope formed as a result of the reaction ${ }^{127} \mathrm{I}(\mathrm{n}, \gamma){ }^{128} \mathrm{I}$, which is described by the equation: ${ }^{127} \mathrm{I}+{ }^{1} \mathrm{n} \rightarrow{ }^{128} \mathrm{I}+\gamma$. The ${ }^{128} \mathrm{I}$ isotope is instable, and its half-life period T1/2 is 28 minutes. The intensity of the gamma radiation $(\gamma)$ emitted by the disintegrating isotope is counted and used as the measure of the content of iodine-127 (Muramatsu and Yoshida 1993).

Another method of determining total iodine in soil was developed on the basis of inductively coupled plasma mass spectrometry (ICP-MS). This method was successfully tested on 4 reference soil samples, and the iodine content was consistent with the certified values of the reference samples (Yamada et al. 1996a).
The amount of iodine in soils is also determined with the use of the high-performance liquid chromatography (HPLC) method (Yamada et al. 1996b). In this case, preparation for the measurement is done by alkalising a soil sample. Iodine in the form of iodates is separated on a C-18-bonded phase column with the mobile phase in the form of acetonitrile-water containing tetrabutylammonium ions. This method makes it possible to determine the total amount of iodine reaching more than $1\left[\mathrm{mg} \cdot \mathrm{kg}^{-1}\right]$ in soils. Application of this method also allows for quantitative speciation of water soluble iodine in soil. Iodine in the water extract of soil was divided into iodide $\mathrm{I}^{-}$, iodate $\mathrm{IO}_{3}^{-}$ and organically bound iodine, and the studies revealed that the predominant chemical form of iodine in the extract was the iodide anion $\mathrm{I}^{-}$(Yamada et al. 1996b).

Contemporary pedology still fairly often uses spectral research methods. Developing the method presented in this article used VIS spectrophotometric analysis, which works well in quantitative analysis and chemical kinetics. The basis for studying the kinetics of chemical reactions is the different capacity of reaction substrates and products for absorbing or transmitting radiation. Using the absorbance or transmittance differences between reaction substrates and products allows for changes of substance concentration to be traced in time. A great advantage of VIS methods is their high sensitivity, and a successful analysis can sometimes be performed with as little as several thousandths of milligram of a given substance.

The aim of this study was to prepare, develop, verify and describe a method for determining iodine contents in soil samples on the basis of colourimetry. 


\section{MATERIALS AND RESEARCH METHODOLOGY}

The starting point for analytical work was the method for determining iodine in vegetable samples published by Borst Pauwels and van Wasemael (1962) and its modification presented in the works of Kollender-Szych (1983a, 1983b). Using the above descriptions and own trials and reflections, after introducing many changes, improvements and modifications, the desired analytical effect was achieved. It was possible to effectively develop and verify the presented method for determination of iodine ${ }^{127} \mathrm{I}$ in soil.

The method is based on the phenomenon of catalyzing by the iodide anion the reduction of cerium IV cations $\left[\mathrm{Ce}^{4+}\right]$ by arsenic from the anion of arsenic acid III $\left[\mathrm{AsO}_{3}{ }^{3-}\right]$ in acidic environment, where the reaction products are cerium III cations $\left[\mathrm{Ce}^{3+}\right]$ and anions of arsenic acid $\mathrm{V}\left[\mathrm{AsO}_{4}{ }^{3-}\right]$. Without the catalyst, this reaction progresses very slowly, despite a considerable difference of the redox potential of both systems. If traces of iodides are found in the solution, the reaction progresses much faster (from several to several dozen minutes), and the reaction rate is directly proportional to the concentration of iodides.

In the process of mineralisation of soil samples, iodine from organic bonds is oxidised to iodates $(\mathrm{V})$ $\left[\mathrm{IO}_{3}{ }^{-}\right]$. Soil after mineralisation provides the supply of iodine in the form of iodates (V). If e.g. $1 \mathrm{~cm}^{3}$ of such solution after soil mineralisation is placed in the cuvette and $0.5 \mathrm{~cm}^{3}$ of arsenous acid (III) $\mathrm{H}_{3} \mathrm{AsO}_{3}$ is added (in large excess), a chain of reactions will take place:

$$
\begin{aligned}
& \mathrm{IO}_{3}{ }^{-}+\mathrm{AsO}_{3}{ }^{3-} \rightarrow \mathrm{IO}_{2}{ }^{-}+\mathrm{AsO}_{4}{ }^{3-} \\
& \mathrm{IO}_{2}{ }^{-}+\mathrm{AsO}_{3}{ }^{3-} \rightarrow \mathrm{IO}^{-}+\mathrm{AsO}_{4}{ }^{3-} \\
& \mathrm{IO}^{-}+\mathrm{AsO}_{3}{ }^{3-} \rightarrow \mathrm{I}^{-}+\mathrm{AsO}_{4}{ }^{3-} \\
& \text { or more simply: } \\
& \mathrm{IO}_{3}{ }^{-}+3 \mathrm{AsO}_{3}{ }^{3-} \rightarrow \mathrm{I}^{-}+3 \mathrm{AsO}_{4}{ }^{3-}
\end{aligned}
$$

which consist in the reduction of iodates $\left[\mathrm{IO}^{3-}\right]$ to iodides $\left[\mathrm{I}^{-}\right]$, i.e. to the form of the catalytic agent.

If we add $1.0 \mathrm{~cm}^{3}$ of water, $0.5 \mathrm{~cm}^{3}$ of arsenic acid (III) $\mathrm{H}_{3} \mathrm{AsO}_{3}$ and $1.0 \mathrm{~cm}^{3}$ of yellow solution of $\mathrm{Ce}^{4+}$ salt to the cuvette (the so-called blank test), then the following reaction will occur: $2 \mathrm{Ce}(\mathrm{IV})+\mathrm{As}(\mathrm{III})$ $\rightarrow 2 \mathrm{Ce}(\mathrm{III})+\mathrm{As}(\mathrm{V})$. This reaction progresses at a low rate, the discolouration of the yellow solution is slight even after 20 minutes, which confirms the analysis result of the blank test (Table 1).
TABLE 1. Example results of transmittance $T$ measurements for standards

\begin{tabular}{lllcl}
\hline$\#$ & $\mathrm{mg} \mathrm{I}^{-}$in $1 \mathrm{~cm}^{3}$ & $T_{0.5}$ & $T_{20}$ & $\Delta T=T_{20}-T_{0.5}$ \\
\hline 1 & 0.0 (blank test) & 0.7 & 2.3 & 1.6 \\
2 & 0.00001 & 0.7 & 12.7 & 12.0 \\
3 & 0.00002 & 0.8 & 27.3 & 26.5 \\
4 & 0.00004 & 0.8 & 52.9 & 52.1 \\
5 & 0.00006 & 0.9 & 74.7 & 73.8 \\
6 & 0.00008 & 0.8 & 88.4 & 87.6 \\
7 & 0.00010 & 1.0 & 94.7 & 93.7 \\
8 & 0.00012 & 1.2 & 97.1 & 95.9 \\
9 & 0.00014 & 1.4 & 98.2 & 96.8 \\
\hline
\end{tabular}

The catalytic action of iodides $\left[\mathrm{I}^{-}\right]$can be explained by the rapid oxidation by cerium ions $\left[\mathrm{Ce}^{4+}\right]$ of iodide anions $\left[\mathrm{I}^{-}\right]$to molecular iodine $\left[\mathrm{I}_{2}\right]$ as per reaction (1). The molecular iodine $\mathrm{I}_{2}$, formed as a result of reaction (1), is reduced by $\mathrm{AsO}_{3}{ }^{3-}$ anions (arsenic III) to iodides $\mathrm{I}^{-}$as per equation (2), as a result of which $\mathrm{AsO}_{4}{ }^{3-}$ anions (arsenic $\mathrm{V}$ ) originate.

$$
\begin{aligned}
& 2 \mathrm{Ce}^{4+}+2 \mathrm{I}^{-} \rightarrow 2 \mathrm{Ce}^{3+}+\mathrm{I}_{2} \\
& \mathrm{I}_{2}+\mathrm{H}_{2} \mathrm{O}+\mathrm{AsO}_{3}{ }^{3-} \rightarrow 2 \mathrm{I}^{-}+\mathrm{AsO}_{4}{ }^{3-}+2 \mathrm{H}^{+}
\end{aligned}
$$

Reactions (1 and 2) can be expressed in a single equation:

$$
\begin{aligned}
& 2 \mathrm{I}^{-} / \mathrm{I}_{2} \\
& 2 \mathrm{Ce}^{4+}+\mathrm{H}_{2} \mathrm{O}+\mathrm{AsO}_{3}{ }^{3-} \rightarrow 2 \mathrm{Ce}^{3+}+2 \mathrm{H}^{+}+\mathrm{AsO}_{4}{ }^{3-}
\end{aligned}
$$

or even more simply:

$$
2 \mathrm{Ce}(\mathrm{IV})+\mathrm{As}(\mathrm{III}) \rightarrow 2 \mathrm{Ce}(\mathrm{III})+\mathrm{As}(\mathrm{V})
$$

When discolouration (slow decrease of colour intensity) of the reactant mixture occurs during the reaction, determination of $T$ (transmittance) works excellently. By analysing the kinetics of the chemical reaction, we notice the time-dependent change of concentration. At the beginning of the reaction, e.g. in the $30^{\text {th }}$ second, i.e. at time $t=0.5 \mathrm{~min}$., when the reactant mixture has intense colouration, transmittance $T_{0,5}$ is low (Table 1). At time $t$ of $10 \mathrm{~min} ., 20 \mathrm{~min}$., $\left(T_{10}, T_{20}\right.$ respectively), the transmittance increases and approaches $100 \%$ for samples with high iodide contents $\left[\mathrm{I}^{-}\right]$. We use the dependence: $\mathrm{T}_{0}<T_{0.5}$ $<T_{10}<T_{20}$ approaches $100 \%$, i.e. total discolouration of the solution.

\section{Apparatus and instrumentation}

- any kit for mineralisation of soil samples;

- glass volumetric flasks $\left(50 \mathrm{~cm}^{3}\right)$ or Falcon test tubes $\left(50 \mathrm{~cm}^{3}\right)$;

- centrifuge; 
- spectrophotometer with the wavelength range including: $\lambda=410-440 \mathrm{~nm}$;

- disposable macro cuvettes with the thickness of absorbing layer of: $l=1 \mathrm{~cm}$;

- automatic measuring pipettes.

\section{Reagents and solutions}

- concentrated $\mathrm{H}_{2} \mathrm{SO}_{4}\left(\gamma=1.84 \mathrm{~kg} \cdot \mathrm{dm}^{-3}\right)$;

- concentrated $\mathrm{HNO}_{3}\left(\gamma=1.40 \mathrm{~kg} \cdot \mathrm{dm}^{-3}\right)$;

- concentrated $\mathrm{HClO}_{4}\left(\gamma=1.67 \mathrm{~kg} \cdot \mathrm{dm}^{-3}\right)$;

- concentrated $\mathrm{HCl}\left(\gamma=1.19 \mathrm{~kg} \cdot \mathrm{dm}^{-3}\right)$;

- $10 \mathrm{~mol} \cdot \mathrm{dm}^{-3} \mathrm{NaOH} \gamma 40 \mathrm{~g} \mathrm{NaOH}$ in $100 \mathrm{~cm}^{3}$ $\mathrm{H}_{2} \mathrm{O}$;

- $1 \mathrm{~mol} \cdot \mathrm{dm}^{-3} \mathrm{H}_{2} \mathrm{SO}_{4}-53.6 \mathrm{~cm}^{3}$ of concentrated $\mathrm{H}_{2} \mathrm{SO}_{4}$ in $1000 \mathrm{~cm}^{3} \mathrm{H}_{2} \mathrm{O}$;

- $\mathrm{H}_{3} \mathrm{AsO}_{3}\left(c=0.1 \mathrm{~mol} \cdot \mathrm{dm}^{-3}\right)-9.9 \mathrm{~g} \mathrm{As}_{2} \mathrm{O}_{3}(0.05$ mol $\mathrm{As}_{2} \mathrm{O}_{3}$ ) dissolved in $14-15 \mathrm{~cm}^{3} 10 \mathrm{~mol} \cdot \mathrm{dm}^{-3}$ $\mathrm{NaOH}$ (as per equation: $\mathrm{As}_{2} \mathrm{O}_{3}+6 \mathrm{OH}^{-} \rightarrow 2 \mathrm{AsO}_{3}^{-3}$ $+3 \mathrm{H}_{2} \mathrm{O}$ ) in order to obtain $1000 \mathrm{~cm}^{3}$ of $\mathrm{H}_{3} \mathrm{AsO}_{3}$ solution of arsenic acid (III), concentration $0.1^{3}$ $\mathrm{mol} \cdot \mathrm{dm}^{-3}$, the whole must be diluted by adding $700-800 \mathrm{~cm}^{3}$ of distilled $\mathrm{H}_{2} \mathrm{O}$, and acidified by adding approx. $40 \mathrm{~cm}^{3}$ of concentrated $\mathrm{H}_{2} \mathrm{SO}_{4}$, shake by hand and add $10 \mathrm{~cm}^{3}$ of concentrated $\mathrm{HCl}$, the whole must be made up with $\mathrm{H}_{2} \mathrm{O}$ to $1000 \mathrm{~cm}^{3}$;

- solution $0.015 \mathrm{~mol} \cdot \mathrm{dm}^{-3} \mathrm{Ce}^{+4}$, i.e. the cerium salt, must be recalculated to cerium $\mathrm{Ce}$, whose molar mass is $\mathrm{M}=140.1 \mathrm{~g} \cdot \mathrm{mol}^{-1}$ and hence: $0.015 \mathrm{~mol} \cdot 140.1 \mathrm{~g} \cdot \mathrm{mol}^{-1}=2.1 \mathrm{~g} \mathrm{Ce}$ in $1 \mathrm{dm}^{3}$ of the salt solution. Below are examples of analytical samples of the salt which will contain $2.1 \mathrm{~g}$ Ce. Cerium salts include: $\left(\mathrm{NH}_{4}\right)_{4} \mathrm{Ce}\left(\mathrm{SO}_{4}\right)_{4}$ or $\mathrm{Ce}\left(\mathrm{SO}_{4}\right)_{2} \cdot 4 \mathrm{H}_{2} \mathrm{O}$. Molar mass of the salt $\left(\mathrm{NH}_{4}\right)_{4} \mathrm{Ce}\left(\mathrm{SO}_{4}\right)_{4}$ is $\mathrm{M}=596.5 \mathrm{~g} \cdot \mathrm{mol}^{-1}$ so the analytical sample of $8.9 \mathrm{~g}$ of the salt in $1 \mathrm{dm}^{3}$ of solution, for $\mathrm{Ce}\left(\mathrm{SO}_{4}\right)_{2} \cdot 4 \mathrm{H}_{2} \mathrm{O}(\mathrm{M}=404.3$ $\mathrm{g} \cdot \mathrm{mol}^{-1}$ ) so the analytical sample of $6.1 \mathrm{~g}$ of the salt in $1 \mathrm{dm}^{3}$ of solution. The salt sample must be dissolved in 1 litre of $1 \mathrm{~mol} \cdot \mathrm{dm}^{-3}$ $\mathrm{H}_{2} \mathrm{SO}_{4}$. Concentration of the $\mathrm{Ce}^{+4}$ solution must be controlled so that after mixing $1 \mathrm{~cm}^{3}$ of this solution with $7 \mathrm{~cm}^{3}$ of distilled $\mathrm{H}_{2} \mathrm{O}$, absorbance A measured with the spectrophotometer (for cuvette thickness of $l=1 \mathrm{~cm}$ and wavelength of $\lambda=420 \mathrm{~nm}$ ), should be close to 0.7 . The solution is very stable (more than a year);

- potassium iodide, solution A: $0.1\left[\mathrm{~g}\left(\mathrm{I}^{-}\right) \cdot \mathrm{dm}^{-3}\right]$ $\equiv 0.1\left[\mathrm{mg}\left(\mathrm{I}^{-}\right) \cdot \mathrm{cm}^{-3}\right]$ analytical sample of $0.1308 \mathrm{~g}$ $\mathrm{KI}$ i.e.: $0.1000 \mathrm{~g} \mathrm{I}^{-}$, dissolve in $1 \mathrm{dm}^{3}$ of distilled $\mathrm{H}_{2} \mathrm{O}$;

- potassium iodide, solution B: $0.001\left[\mathrm{~g}\left(\mathrm{I}^{-}\right) \cdot \mathrm{dm}^{-3}\right]$ $\equiv 0.001\left[\mathrm{mg}\left(\mathrm{I}^{-}\right) \cdot \mathrm{cm}^{-3}\right]$, batch $10 \mathrm{~cm}^{3}$ of solution
A to a $1 \mathrm{dm}^{3}$ flask and make up with distilled $\mathrm{H}_{2} \mathrm{O}$ to $1000 \mathrm{~cm}^{3}$.

\section{Performing the analysis}

The method for determining iodine in soil is as follows. Weigh $2 \mathrm{~g}$ of dry or fresh soil. For fresh soil, insert its dry weight into the final formula (3). The soil sample must be mineralised using the apparatus available in the laboratory. The author mineralised the sample for 2 hours in a mixture of concentrated acids: $7 \mathrm{~cm}^{3}$ of concentrated $\mathrm{H}_{2} \mathrm{SO}_{4}, 7 \mathrm{~cm}^{3}$ of concentrated $\mathrm{HNO}_{3}$ and $1 \mathrm{~cm}^{3}$ of concentrated $\mathrm{HClO}_{4}$, $15 \mathrm{~cm}^{3}$ in total, at the temperature increasing from 160 to $180^{\circ} \mathrm{C}$, and after cooling and diluting with water, he obtained exactly $50 \mathrm{~cm}^{3}$ of solution which corresponded to $2 \mathrm{~g}$ of soil.

In order to obtain a sample for analysis after mineralisation, it must be centrifuged or left for a couple of hours, for sand grains to sediment. The shorter, the better. In the solution after mineralisation, all iodine form organic bonds should be in the form of anions $\left[\mathrm{IO}_{3}{ }^{-}\right]$and it is so, but to avoid the possible disproportionation reaction: $\mathrm{IO}_{3}^{-}+5 \mathrm{I}^{-}+6 \mathrm{H}^{+} \rightarrow 3 \mathrm{I}_{2} \uparrow+3 \mathrm{H}_{2} \mathrm{O}$ and loss of gaseous iodine from the sample, the analysis should not be delayed. All the prepared solutions and reagents must be at the same or similar temperature of $22-24^{\circ} \mathrm{C}$.

\section{Preparation of standards and drawing the analytical curve}

To 9 Falcon test tubes $\left(50 \mathrm{~cm}^{3}\right)$ or glass volumetric flasks $\left(50 \mathrm{~cm}^{3}\right)$, batch in succession: $0.0 ; 0.5 ; 1.0$; $2.0 ; 3.0 ; 4.0 ; 5.0 ; 6.0 ; 7.0 \mathrm{~cm}^{3}$ of solution $\mathrm{B}$ at the concentration of $0.001\left[\mathrm{mg}\left(\mathrm{I}^{-}\right) \cdot \mathrm{cm}^{-3}\right]$ and make up with distilled $\mathrm{H}_{2} \mathrm{O}$ to $50 \mathrm{~cm}^{3}$, which corresponds to the concentration of: $0.0 ; 0.00001 ; 0.00002 ; 0.00004$; $0.00006 ; 0.00008 ; 0.00010 ; 0.00012 ; 0.00014\left[\mathrm{mg}\left(\mathrm{I}^{-}\right) \cdot \mathrm{cm}^{-3}\right]$. In this way, 9 solutions for the analytical curve were obtained. Before and during determination, the laboratory should be thermostatted to the temperature of $22-24^{\circ} \mathrm{C}$. Before starting the measurements of transmittance $T$, place a cuvette with distilled $\mathrm{H}_{2} \mathrm{O}$ in the spectrophotometer as reference. Place 9 disposable macro cuvettes in the stand and pour $1 \mathrm{~cm}^{3}$ of appropriate standard to each cuvette. The first one is the so-called blank test and the other eight are solutions which contain potassium iodide. Next, inject with an automatic pipette $0.5 \mathrm{~cm}^{3}$ of $\mathrm{H}_{3} \mathrm{AsO}_{3}$ acid to each cuvette and leave for several minutes for the reduction reaction of iodides to iodates to take place. The injection results in a very good mixing of the solutions and facilitates the course of the reaction (no need for 
stirring). After several minutes, activate a digital stopwatch. At the first minute and 00 seconds (1:00), inject $1 \mathrm{~cm}^{3}$ of $\mathrm{Ce}^{+4}$ salt solution to the first cuvette. Place the first cuvette (containing already $2.5 \mathrm{~cm}^{3}$ of the mixture of solutions) in the spectrophotometer as soon as possible and, precisely at the $30^{\text {th }}$ second of the reaction (1:30), read off the transmittance value $T_{0.5}$. Remove the cuvette from the spectrophotometer and replace it on the stand. Prepare for injecting $1 \mathrm{~cm}^{3}$ of cerium salt into the second cuvette and do so at the second full minute $(2: 00)$. Then, insert the second cuvette in the spectrophotometer and read off at the $30^{\text {th }}$ second $T_{0.5}$ for the second standard (2:30) and so on. Close to the end of the $20^{\text {th }}$ minute of the reaction in the first cuvette, place it in the spectrophotometer and, precisely at 20 minutes and 00 seconds, read off the transmittance $T_{20}(21: 00)$. Remove the first cuvette from the spectrophotometer and insert the second one. When the digital stopwatch indicates the subsequent full minute (22:00), $T_{20}$ must be read off for the second standard and so on. Chemical reactions were allowed to proceed for exactly 20 minutes ( $\pm 2 \mathrm{sec})$.

Draw the analytical curve by marking on the argument axis (X-axis) the contents of iodides in $\mathrm{mg}$ $\mathrm{I}^{-}$(in the analysed $1 \mathrm{~cm}^{3}$ ), which corresponds to the concentration $\left[\mathrm{mg}\left(\mathrm{I}^{-}\right) \cdot \mathrm{cm}^{-3}\right]$, and on the axis of function values - the measured transmittance $T$ of the standard solutions. It seems that drawing the following function: $T_{20}=\mathrm{f}\left(\mathrm{mg} \mathrm{I}^{-}\right)$is sufficient.

It follows from Table 1 and Figure 1 that the characteristics of the functions: $T_{20}$ or $\Delta T$ are very similar. However, the analytical curve should be a linear function and not a polynomial one (as in the above diagrams). The diagrams confirm the assumptions of the method and the reactions which take place during determination. As long as there is a large amount of yellow cerium cations $\mathrm{Ce}^{+4}$ in the cuvette, discolouration of the mixture (reduction of $\mathrm{Ce}^{+4}$ to $\mathrm{Ce}^{+3}$ ) is linearly related to the concentration (amount) of iodide anions $\left(\mathrm{I}^{-}\right)$. When most cerium (IV) cations have been reduced, the mixture is close to complete discolouration and the transmittance approaches $100 \%$.

Correct readout of values of functions $T_{20}$ or $\Delta T$ for arguments greater than $0.00008 \mathrm{mg} \mathrm{I}^{-}$in $1 \mathrm{~cm}^{3}$ $\left[\mathrm{mg}\left(\mathrm{I}^{-}\right) \cdot \mathrm{cm}^{-3}\right]$ is not possible. In order to draw a proper analytical curve, the amount of iodides in the standards must be limited to $0.00006\left[\mathrm{mg}\left(\mathrm{I}^{-}\right) \cdot \mathrm{cm}^{-3}\right]$.

On the basis of Table 1, the analytical curve from 6 samples (a) up to $0.00008 \mathrm{mg} \mathrm{I}^{-}$in $1 \mathrm{~cm}^{3}$ and 5 samples (b) up to $0.00006 \mathrm{mg} \mathrm{I}^{-}$in $1 \mathrm{~cm}^{3}$ is presented in Figure 2. The choice and final decisions are at the researcher's discretion.

\section{Colorimetric determination}

It is convenient to determine a series of 20 solutions, including e.g.: 18 soil extracts and 2 blank tests (for certainty). The measurement cycle lasts 40 minutes and is the same as with the standards. Use distilled $\mathrm{H}_{2} \mathrm{O}$ as reference. In each of 18 macro cuvettes, place $1 \mathrm{~cm}^{3}$ of different soil extracts, and in 2 macro cuvettes $-1 \mathrm{~cm}^{3}$ of distilled $\mathrm{H}_{2} \mathrm{O}$. Inject $0.5 \mathrm{~cm}^{3}$ of the $\mathrm{H}_{3} \mathrm{AsO}_{3}$ acid into each cuvette and leave for several minutes. Activate a stopwatch and after 1 minute, analyse the prepared solutions in the same way as the standards - inject $1 \mathrm{~cm}^{3}$ of cerium salt, measure the transmittance $T_{0.5}$ and $T_{20}$, i.e. at the intervals of 19 minutes and 30 seconds.

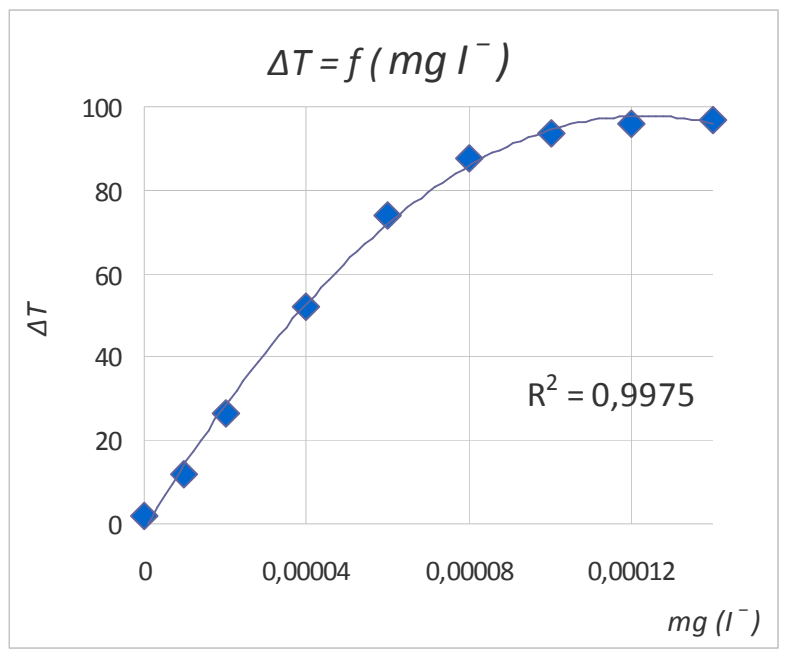

b

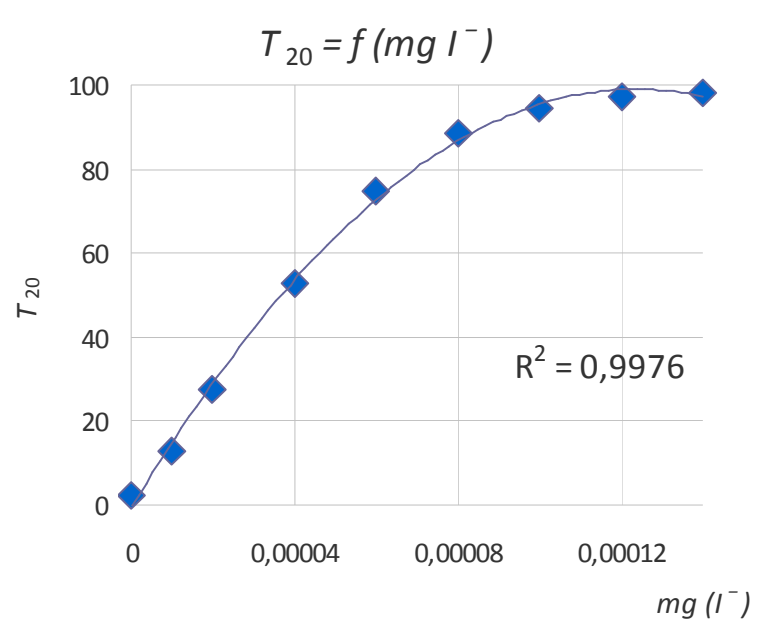

FIGURE 1. Useless diagrams of analytical curves 

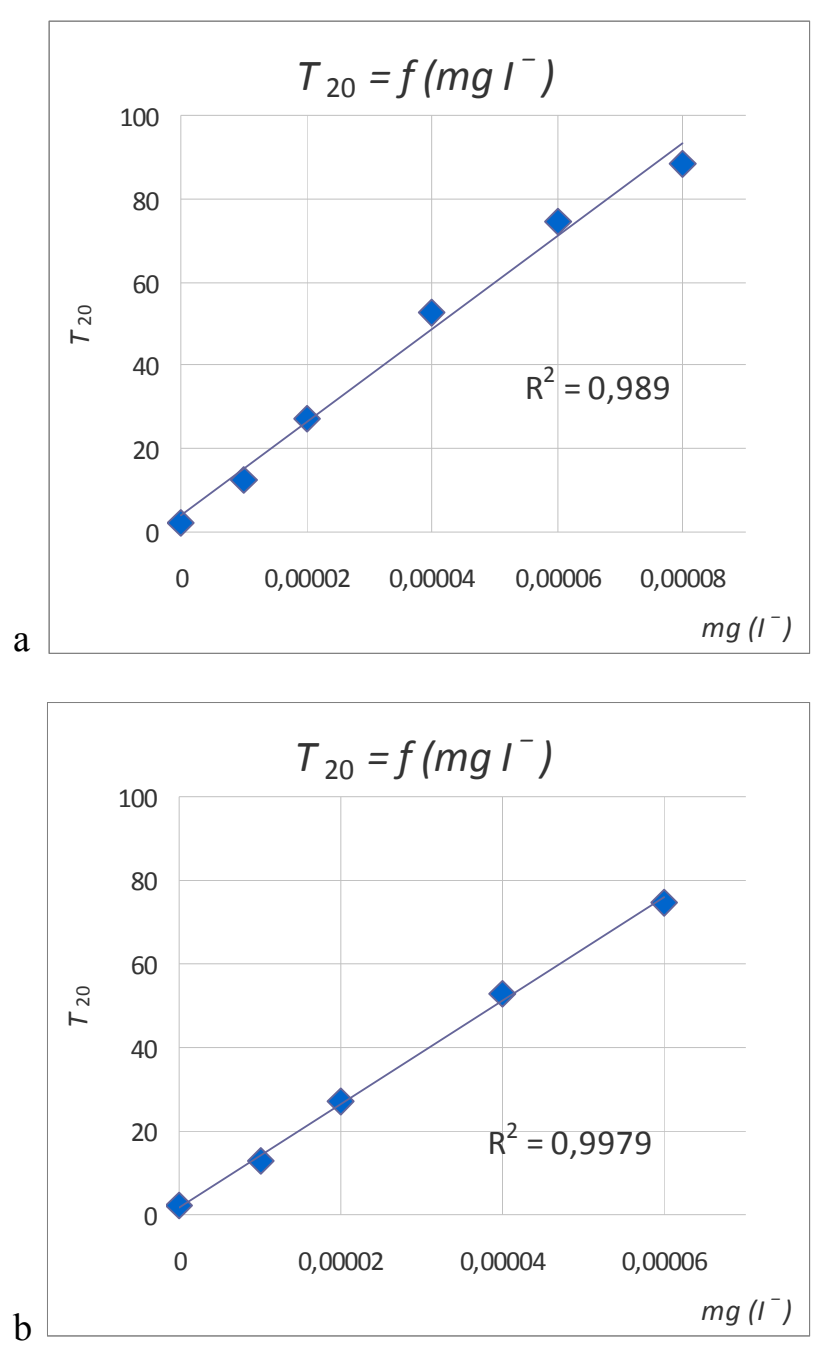

FIGURE 2. Correct diagrams of analytical curves

If, during determination, before the lapse of the $20^{\text {th }}$ minute, the transmittance $T$ exceeds $80 \%$, the determination must be repeated, placing in the cuvette instead of: $v=1 \mathrm{~cm}^{3}$ of the soil extract, e.g.: $v=0.7 \mathrm{~cm}^{3}$ of the extract and $0.3 \mathrm{~cm}^{3}$ of distilled $\mathrm{H}_{2} \mathrm{O}$ or $v=0.5 \mathrm{~cm}^{3}$ of the extract and $0.5 \mathrm{~cm}^{3}$ of distilled $\mathrm{H}_{2} \mathrm{O}$ (still no changes). This change is accounted for in the final formula, where we replace $\mathrm{v}$ with the real volume of the soil extract, where: $v \leq 1 \mathrm{~cm}^{3}$.

The sum of volumes in the cuvette must be constant and amount to $2.5 \mathrm{~cm}^{3}$, which consists of:

- the volume $v$ of the soil extract + possibly water ( $1 \mathrm{~cm}^{3}$ altogether),

- the volume of the solution of $\mathrm{H}_{3} \mathrm{AsO}_{3}$ acid $(0.5$ $\mathrm{cm}^{3}$ ),

- the volume of the solution of cerium salt $\left(1 \mathrm{~cm}^{3}\right)$.
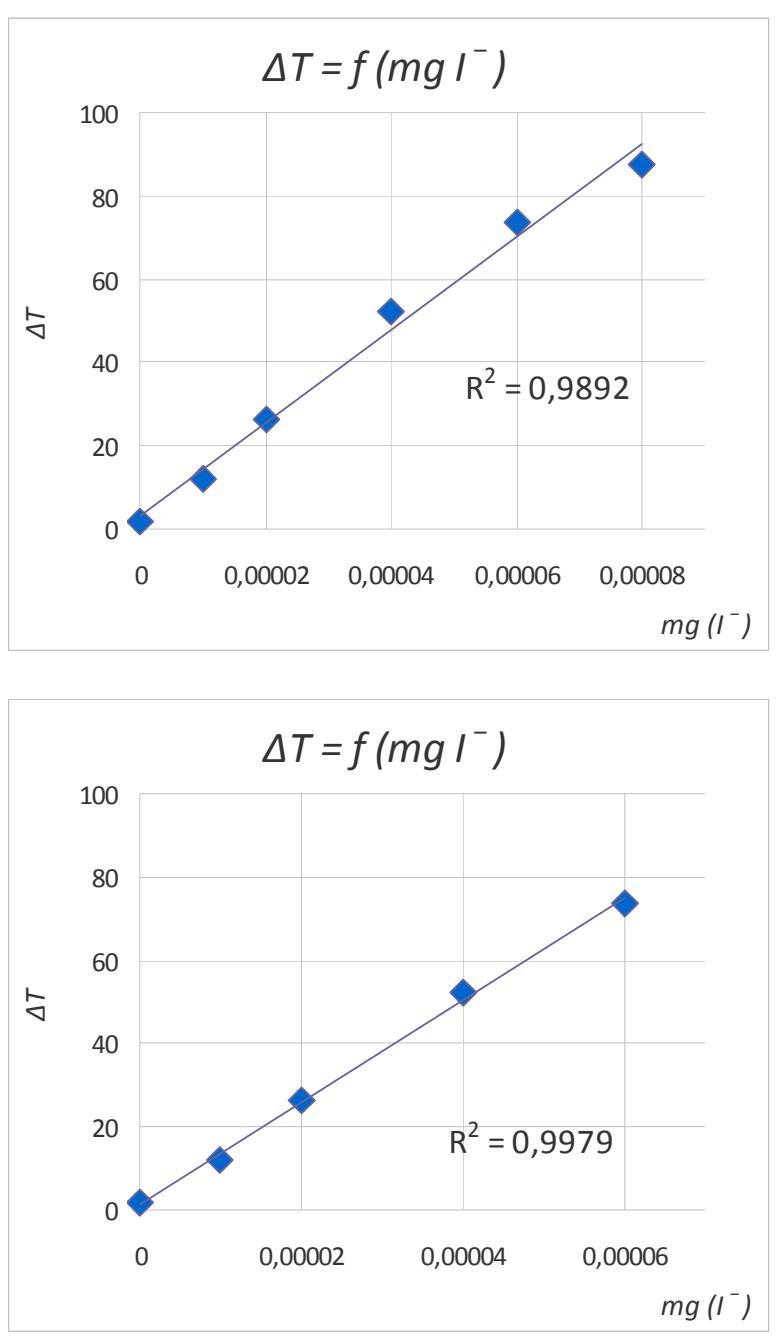

Calculating the result of the determination

The content of iodides in the analysed soil sample $(X)$ must be calculated in $\left[\mathrm{mg} \cdot \mathrm{kg}^{-1}\right]$ using formula (3):

(3) $X=c \times 500 \times 50 \times \frac{2}{m} \times \frac{1}{v}$

$[X]=\left[\frac{\mathrm{mg}}{\mathrm{cm}^{3}} \times \frac{\mathrm{g}}{\mathrm{kg}} \times \frac{\mathrm{cm}^{3}}{\mathrm{~g}} \times \frac{\mathrm{g}}{\mathrm{g}} \times \frac{\mathrm{cm}^{3}}{\mathrm{~cm}^{3}}\right]=\left[\frac{\mathrm{mg}}{\mathrm{kg}}\right]$

in which:

$c$ - the content of iodides in the cuvette $\left(1 \mathrm{~cm}^{3}\right.$ of soil extract) read off the analytical curve in $\left[\mathrm{mg} \cdot \mathrm{cm}^{-3}\right]$

500 - recalculation of the 2-gram analytical sample to $1 \mathrm{~kg}$ of soil in $\left[\mathrm{g} \cdot \mathrm{kg}^{-1}\right]$,

50 - recalculation of $1 \mathrm{~cm}^{3}$ of soil extract to $2 \mathrm{~g}$ of mineralised soil in $\left[\mathrm{cm}^{3} \cdot \mathrm{g}^{-1}\right]$,

$\frac{2}{m}$ - correction for the inaccuracy of mass of the analytical sample of soil for mineralisation $\left[\mathrm{g} \cdot \mathrm{g}^{-1}\right]$, in which: $m-$ is the dry weigh of the real 
analytical sample of fresh soil, taken for mineralisation, between 1 and 3 [g]

$\frac{1}{v}-$ correction $\left[\mathrm{cm}^{3} \cdot \mathrm{cm}^{-3}\right]$ for reduced volume of

the soil extract,

in which: $v$ - real volume $\leq 1\left[\mathrm{~cm}^{3}\right]$ of soil extract in the cuvette, possibly made up with water to the volume of $1 \mathrm{~cm}^{3}$

or in a simplified form:

$$
X=\frac{c \times 50000}{m \times v} \text { or } X=\frac{c \times 5 \times 10^{5}}{m \times v}
$$

in which:

$c, m, v-$ as above

50000 or $5 \times 10^{5}-$ multiplier in $\left[\mathrm{g} \cdot\left(\mathrm{cm}^{3}\right)^{2} \cdot \mathrm{kg}^{-1}\right]$.

\section{DISCUSSION AND INTERPRETATION}

Example calculations of iodine contents in soil samples are presented below.

\section{Example 1}

$1.89 \mathrm{~g}$ of fresh soil was used for mineralisation. Its dry weight is: $m=1.76 \mathrm{~g} .1 \mathrm{~cm}^{3}$ of soil extract was analysed. Transmittance values $T_{0.5}$ and $T_{20}$ were 0.8 and $64.4 \%$ respectively. Difference: $\Delta T=T_{20}-T_{0.5}=63.6$. It was read off the diagram of the analytical curve that $c=0.000055\left[\mathrm{mg} \cdot \mathrm{cm}^{-3}\right]$. The amount of $\mathrm{mg}$ of iodine in $1 \mathrm{~kg}$ of soil is calculated with the use of the following formula:

$$
X=\frac{c \times 50000}{m \times v}=\frac{0.000055 \times 50000}{1.76 \times 1}=1.56 \mathrm{mg}\left(\mathrm{I}^{-}\right) \cdot \mathrm{kg}^{-1}(\text { soil })
$$

\section{Example 2}

$1.39 \mathrm{~g}$ of fresh soil was used for mineralisation. Its dry weight is: $m=1.26 \mathrm{~g} .1 \mathrm{~cm}^{3}$ of soil extract was analysed. Transmittance values $T_{0.5}$ and $T_{20}$ were 1.8 and $98.4 \%$ respectively. The determination was repeated, decreasing the volume of soil extract by a half. $0.5 \mathrm{~cm}^{3}$ of soil extract and $0.5 \mathrm{~cm}^{3}$ of distilled $\mathrm{H}_{2} \mathrm{O}$ were injected into the cuvette and the further procedure was not changed: solution of $\mathrm{H}_{3} \mathrm{AsO}_{3}$ acid $\left(0.5 \mathrm{~cm}^{3}\right)$ and solution of cerium salt $\left(1 \mathrm{~cm}^{3}\right)$. New transmittance values were obtained: $T_{0.5}=0.9 \%$ and $T_{20}=71.3 \%$. Difference: $\Delta T=T_{20}-T_{0.5}=70.4$. It was read off the diagram of the analytical curve that $c=0.00006$ $\left[\mathrm{mg} \cdot \mathrm{cm}^{-3}\right]$. The amount of iodine in $1 \mathrm{~kg}$ of soil is calculated with the use of the following formula:

$$
X=\frac{c \times 50000}{m \times v}=\frac{0.00006 \times 50000}{1.26 \times 0.5}=4.76 \mathrm{mg}\left(\mathrm{I}^{-}\right) \cdot \mathrm{kg}^{-1}(\text { soil })
$$

\section{Final result of determination}

The final result of determination should be the arithmetic mean of the values of two determinations conducted in parallel, which differ by not more than $5 \%$ of the lower result and standard deviation.

\section{Verification of the method}

Accuracy of the method was verified on the basis of inorganic standards. Verification of the method and results presented in this work was performed with the use of an analytical sample manufactured by POCH SA: TitraFix ${ }^{\mathrm{TM}}$, analytical sample of potassium iodate-iodide $0.05 \mathrm{~mol} \cdot \mathrm{dm}^{-3} \mathrm{I}_{2}(0.1 \mathrm{~N})$, (index: $743110161-020-1$, tolerance range: $\pm 0.2 \%$ ). Salts were transferred from a glass vial, which contained $3.567 \mathrm{~g}$ of $\mathrm{KIO}_{3}$ and $35.0 \mathrm{~g} \mathrm{KI}$, to a $1 \mathrm{dm}^{3}$ flask.
$3.567 \mathrm{~g} \mathrm{KIO}_{3}\left(\mathrm{M}_{\mathrm{KIO} 3}=214 \mathrm{~g} \cdot \mathrm{mol}^{-1}\right)$ $35.0 \mathrm{~g} \mathrm{KI}\left(\mathrm{M}_{\mathrm{KI}}=166 \mathrm{~g} \cdot \mathrm{mol}^{-1}\right)$ which is $2.12 \mathrm{~g}$ of iodine which is $26.78 \mathrm{~g}$ of iodine
Total:

$28.90 \mathrm{~g}$ of iodine

The contents of the vial ( $28.90 \mathrm{~g}$ of iodine) was placed in a $1000 \mathrm{~cm}^{3}$ flask, dissolved in approx. 800 $\mathrm{cm}^{3}$ of distilled $\mathrm{H}_{2} \mathrm{O}, 10-15 \mathrm{~cm}^{3}$ of concentrated $\mathrm{HCl}$ were added and made up to the mark with water, obtaining solution P. Of the $28.9 \mathrm{~g}$ of iodine in the flask, $12.7 \mathrm{~g}$ is the molecular $\mathrm{I}_{2}$, and 16.2 are the iodide anions $\mathrm{I}^{-}$(excess). It is illustrated with the following formula:

$$
\mathrm{IO}_{3}^{-}+5 \mathrm{I}^{-}+6 \mathrm{H}^{+} \rightarrow 3 \mathrm{I}_{2}+3 \mathrm{H}_{2} \mathrm{O}
$$

$2.12 \mathrm{~g}$ (iodine in $\mathrm{IO}_{3}^{-}$) $+10.58 \mathrm{~g}$ (iodine in $\mathrm{I}^{-}$) $\rightarrow 12.70 \mathrm{~g}$ (molecular iodine $\mathrm{I}_{2}$ ).

By diluting solution $\mathrm{P}-1: 500\left(2 \mathrm{~cm}^{3}\right.$ of solution $P$ in a $1000 \mathrm{~cm}^{3}$ flask was made up with distilled water) solution $\mathrm{R}$ was obtained, 1 litre of which contains $0.0578 \mathrm{~g}\left(\mathrm{I}_{2}+\mathrm{I}^{-}\right)$or $1 \mathrm{~cm}^{3} 0.0578 \mathrm{mg}\left(\mathrm{I}_{2}+\mathrm{I}^{-}\right)$respectively. Solution $\mathrm{R}$ was diluted five times $1: 5\left(1 \mathrm{~cm}^{3}\right.$ of solution $\mathrm{R}$ and $4 \mathrm{~cm}^{3}$ of distilled $\mathrm{H}_{2} \mathrm{O}$ ) and $5 \mathrm{~cm}^{3}$ of solution $\mathrm{S}$ was obtained, $1 \mathrm{~cm}^{3}$ of which contained $0.0115 \mathrm{mg}$ $\left(\mathrm{I}_{2}+\mathrm{I}^{-}\right)$. Three samples of solution $\mathrm{S}$ were mineralised: $0.1 \mathrm{~cm}^{3}, 0.2 \mathrm{~cm}^{3}$ and $0.4 \mathrm{~cm}^{3}$, being treated as soil samples $\left(7 \mathrm{~cm}^{3}\right.$ of concentrated $\mathrm{H}_{2} \mathrm{SO}_{4}, 7 \mathrm{~cm}^{3}$ of concentrated $\mathrm{HNO}_{3}$ and $1 \mathrm{~cm}^{3}$ of concentrated $\mathrm{HClO}_{4}$ ). The samples contained $0.00115,0.0023$ and $0.0046 \mathrm{mg}$ of iodine respectively, which, after mineralisation and making up to $50 \mathrm{~cm}^{3}$, gives: $0.000023,0.000046$, $0.000092\left[\mathrm{mg}\left(\mathrm{I}^{-}\right) \cdot \mathrm{cm}^{-3}\right]$ respectively. Proceeding identically as with soil extracts, the transmittance of solutions designed for verification of the method must be measured (Table 2) and their contents of iodides $\left(\mathrm{I}^{-}\right)$compared with the analytical curve (Fig. 3). 
TABLE 2. Results of transmittance $T$ measurements for samples of solution S, compared with the standards

\begin{tabular}{lllll}
\hline$\#$ & $\mathrm{mg} \mathrm{I}^{-}$in $1 \mathrm{~cm}^{3}$ & $T_{0.5}$ & $T_{20}$ & $\Delta T=T_{20}-T_{0.5}$ \\
\hline & 0.0 (blank test) & 0.7 & 2.3 & 1.6 \\
\hline $1 \bullet$ & 0.00001 & 0.7 & 12.7 & 12.0 \\
\hline $2 \succ$ & 0.00002 & 0.8 & 27.3 & 26.5 \\
\hline $3 \square$ & 0.000023 & 1.0 & 31.5 & 30.5 \\
\hline $4 \bullet$ & 0.00004 & 0.8 & 52.9 & 52.1 \\
\hline $5 \square$ & 0.000046 & 1.1 & 61.7 & 60.6 \\
\hline $6 \bullet$ & 0.00006 & 0.9 & 74.7 & 73.8 \\
\hline 0.00008 & 0.8 & 88.4 & 87.6 \\
\hline 0.00010 & 1.0 & 94.7 & 93.7 \\
\hline 0.000092 & 1.3 & 95.8 & 94.5 \\
\hline 0.00012 & 1.2 & 97.1 & 95.9 \\
\hline 0.00014 & 1.4 & 98.2 & 96.8 \\
\hline
\end{tabular}

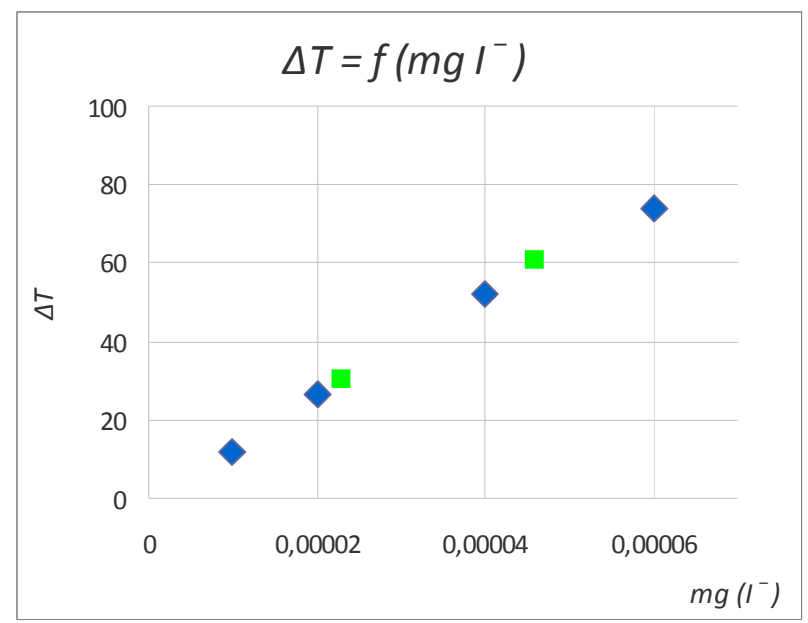

FIGURE 3. Diagram of dependence between transmittance and iodide $\mathrm{I}^{-}$contents in $1 \mathrm{~cm}^{3}$ standards $(\diamond)$ and $1 \mathrm{~cm}^{3}$ of samples designed for verification of the method $(\square)$

The diagrams in Figure 3 and Table 3 indicate that verification of the method can be regarded as successful. According to the previous assumption, the method should not be used for direct determination of iodides above $0.00006 \mathrm{mg}$ in $1 \mathrm{~cm}^{3}$ of solution.

\section{CONCLUSIONS}

1. The described method is very sensitive. It allows to estimate the quantity of iodine contents in $2 \mathrm{~g}$ of soil sample.
2. The advantage of the described procedure of iodine determining is possibility of changing the response time among the spectrophotometric measurements $\left(T_{0.5}-T_{20}\right.$ or $\left.T_{0.5}-T_{10}\right)$.

3. The weakness of the above is the necessity of maintaining a constant temperature during reactions for standards and samples in all series of measurements. The best solution is to maintain a constant temperature in the whole laboratory.

\section{REFERENCES}

Borst Pauwels G.W.F.H., van Wesemael J.Ch., 1962. A new routine method for determination of iodine in plant materials. Analytica Chimica Acta 26: 532-540.

Chudecki Z., 1963. Niektóre czynniki, kształtujące zawartość i rozmieszczenie jodu, miedzi oraz cynku w ważniejszych glebach mineralnych Pomorza zachodniego. Zeszyty Naukowe WSR w Szczecinie 10: 187-239.

Dragomirova M.A., 1944. Iodine content in drinking water. Tr. Biogeokhim. Lab., AN SSSR 7: 5-18 (in Russian).

Kollender-Szych A., 1983a. Jod w glebach i wybranych roślinach użytków zielonych Sudetów. Zeszyty Naukowe AR we Wrocławiu 34: 1-39.

Kollender-Szych A., 1983b. Zawartość i rozmieszczenie jodu w glebach górskich Sudetów. Zesz. Probl. Post. Nauk Roln. 242: $75-81$.

Laskowski S., Trawczyńska A., Tołoczko W., 2001. Content of iodine $\left({ }^{127} \mathrm{I}\right)$ in chosen profiles of fen soils of the Pilica and Ner Valleys. [w monografii - red: B. Gworek i A. Mocek] Obieg pierwiastków w przyrodzie: 53-56.

Muramatsu Y., Yoshida S., 1993. Neutron activation analysis of iodine in soil. Journal Radioanal. Nucl. Chem. 169: 73-80.

Proskuriakova G.F., Nikitina O.N., 1976. Rapid kinetic rhodanatenitrite method for determination of microamounts of iodine in biological material (in Russian) Agrochimija 7: 140-143.

Uziak S., Melke J., 1984. Iodine in the soils of the Carpathian foothills and the west Bieszczady mountains. Roczniki Gleboznawcze - Soil Science Annual 35: 43-59.

Yamada H., Kiriyama T., Yonebayashi K., 1996a. Determination of total iodine in soils by inductively coupled plasma mass spectrometry. Soil Science and Plant Nutrition, 42 (4): 859 866.

Yamada H., Sugahara M., Kosaka H., Katayama A., Takahashi K., Yonebayashi K., 1996b. Determination of total and water soluble iodine in soil by high performance liquid chromatography. Soil Science and Plant Nutrition 42 (2): 367-374.

Received: December 19, 2016

Accepted: January 30, 2017

Associated editor: B. Rutkowska

\section{Metoda oznaczania jodu ${ }^{127}$ I w glebach}

Streszczenie: Przedstawiono metodę oznaczania zawartości stabilnego jodu 127 ( $\left.{ }^{127} \mathrm{I}\right) \mathrm{w}$ próbkach glebowych. Metodę opiera się na szybkości reakcji kationu ceru (IV) z anionem arsenowym (III). Szybkość tej reakcji jest katalizowana ilością anionów jodkowych $\left(\mathrm{I}^{-}\right)$w zmineralizowanej próbce gleby. Metoda jest dokładna, wyniki powtarzalne, gotowa do powszechnego stosowania. Sprawdzenie metody zrealizowano na odważce analitycznej produkowanej przez firmę POCH SA: TitraFix ${ }^{\mathrm{TM}}$ odważka analityczna potasu jodan-jodek $0.05 \mathrm{~mol} \cdot \mathrm{dm}^{-3} \mathrm{I}_{2}(0.1 \mathrm{~N})$, (indeks $743110161-020-1$, zakres tolerancji $\pm 0.2 \%$ ).

Stowa kluczowe: jod, gleba, metoda oznaczania 